\title{
The Influence of Entrepreneurial Orientation on Marketing Performance Small and Medium Enterprises (SMEs) in Kuningan Regency Mediated by Creativity of Marketing Program
}

\author{
Tatang Rois', Neng Evi Kartika², Aris Budiman³, Munir Nur Komarudin, Wely Hadi \\ Gunawan 5 \\ Universitas Kuningan, Indonesia \\ \{taro@uniku.ac.id\}
}

\begin{abstract}
Research on the effect of entrepreneurial orientation on marketing performance has been carried out a lot, it's just that more is done in developed countries. This study aims to determine whether entrepreneurial orientation has an influence on marketing performance by including an intervening variable, namely the creativity of the marketing program. This research was conducted on all SMEs in Kuningan Regency engaged in the processing industry using Structural Equation Modeling (SEM) analysis tools. Data collection was carried out by distributing questionnaires. Based on the results of research and data analysis, it is concluded that entrepreneurial orientation and creativity of marketing programs have an effect on marketing performance, and creativity of marketing programs can mediate the relationship between entrepreneurial orientation and marketing performance. This research was conducted in developing countries such as Indonesia. In addition, this study adds a marketing program creativity variable as a mediating variable for the relationship between entrepreneurial orientation and marketing performance
\end{abstract}

Keywords: Marketing Performance; SMEs; Kuningan

\section{Introduction}

Business competition is currently very tight, so that the success of business people in increasing company growth is still very much dependent on the entrepreneurial ability of the owner. Only owners who have strong entrepreneurial behavior (entrepreneurial orientation) are able to bring increased income to the company. The owner's inability to maintain his strength in facing the challenges that exist will actually affect the decline in performance and failure (Smith \& Jambulingam, 2018). Entrepreneurship is currently a major issue because of its influence on the appearance and survival of organizations and because it is a driving force in modern economic and social development (Ferreira \& Coelho, 2020). Over the last decade, studies of corporate entrepreneurship have developed rapidly and tend to be able to improve the performance of superior companies (Dzogbenuku \& Keelson, 2019; Masa'deh et.al, 2018). Entrepreneurship is felt to be part of a successful organization (Ferreira \& Coelho, 2020). Entrepreneurship will be able to create competitive advantage in driving marketing performance (Gunawan, 2018). 
Facing the future era of globalization, the company's dependence on the entrepreneurial orientation of its owners must be accompanied by the company's ability to formulate its strategy. Without the support of the right strategy, companies will find it difficult to survive in the midst of competition (Kang, Hur, \& Kim, 2014). Starting from here, the company demands to be able to formulate a good marketing strategy. Companies need to create creative marketing strategies in line with changing competitive environmental conditions (Slater, Hult, \& Olson, 2010). Research on entrepreneurial orientation in relation to company performance is not new. There have been many studies by several experts on the positive impact of entrepreneurial orientation on marketing performance. Dzogbenuku \& Keelson (2019) dan Smith \& Jambulingam (2018) state that entrepreneurial orientation can drive the success of a business. The entrepreneurial orientation has a positive and significant impact on business development, as well as being an advantage in the eyes of customers (Wahyuni \& Sara, 2020). Other researchers say that entrepreneurial orientation plays an important role in explaining company performance (Jin \& Cho, 2018). Research results by Awang et.al. (2010) stated that entrepreneurial orientation is a very basic resource part of the entrepreneur's soul.

Other researchers have a different opinion from previous researchers, these researchers reject that entrepreneurial orientation has a positive impact on company performance. Baker \& Sinkula (2009) stated that entrepreneurial orientation does not have any impact on firm performance when combined with market orientation. Other researchers say that entrepreneurial orientation in one particular model actually has a negative impact on company performance (Frank et.al., 2010).

This study intends to explain the differences in the results of previous studies. Most of the several previous studies related to entrepreneurial orientation, marketing program creativity, and marketing performance were carried out in the context of a developed western economy by making several large companies the objects of their research (Wahyuni \& Sara, 2020; Kang et al. (2014) and little is done in the context of developing countries, such as Indonesia. In addition, research on entrepreneurial orientation towards marketing performance is still a direct relationship without a mediating variable (Dzogbenuku \& Keelson, 2019). Unlike previous studies, this study includes a mediating variable that bridges the influence of orientation. entrepreneurship on marketing performance The variable that can bridge this relationship is the creativity of the marketing program (Lindsay, 2005).

\section{Method}

The entrepreneurial orientation is related to the search for opportunities, the courage to take risks, and the decision to act from the leaders of the organization and the entrepreneurial orientation will be a value system for the company and will determine the company's movement or strategy. Companies that have the value to keep looking for opportunities will continue to move to try to enter new markets to take the opportunities that are there. Likewise, if the company supports the courage to take risks, they will dare to try new things or strategies or try new businesses that have the opportunity to improve company performance. According to Santos \& Marinho (2018) a person who has an entrepreneurial orientation character always has an autonomous attitude, always innovates, dares to take risks, acts proactively, and is aggressive in competing. The role of entrepreneurial orientation can improve superior company performance has been proven by several previous researchers and is felt to be part of a successful organization (Mamun, et.al, 2018; Sara, 2020). 
Entrepreneurial orientation reflects the tendency of business actors to be involved in innovative behavior, dare to take risks and be proactive to beat competitors (Augusty, 2000). Entrepreneurial orientation is a process that begins in the process of creating creative marketing programs (Lindsay, 2005). Entrepreneurial orientation is also an important lesson that must be possessed in shaping the creativity of a businessman (Lindsay, 2005). A strong entrepreneurial orientation from entrepreneurs is very important because it has a good effect in encouraging one's marketing creativity (Amabile, 1996; Andrews, 1996). In winning business competition, business actors must have a better marketing strategy than their competitors. To realize these strategies, of course, entrepreneurs must have the courage to take risks to create and implement different strategies.

Marketing program creativity is a new thing that has been widely used to describe creativity in advertising. Creativity is an effort to solve business problems that are faced every day. The process of creativity ends when a new product, new idea, new strategy is produced to deal with existing changes. Through creative marketing programs, companies will gain new perspectives that can be used to face the opportunities and threats in the future. Creativity requires the development of newer and more aggressive alternatives so that it can be likened to a motor that offers a new learning process and the potential to change behaviors in organizations (Amabile, 1996).

It must be understood that the creativity of the marketing program is an effort to develop the implementation or application of strategies carried out by organizations in the market to gain opportunities in the future. The search for future opportunities is closely related to a competitive market. The implementation of a better strategy in running a business is an effort to win market competition in the future. This means that if market competition can be achieved, the company's existence will continue. Of course, this strategy is not only for controlling the market, but is also focused on increasing company profits or company performance. The better the creativity of a business actor's marketing program, the better his marketing performance will be.

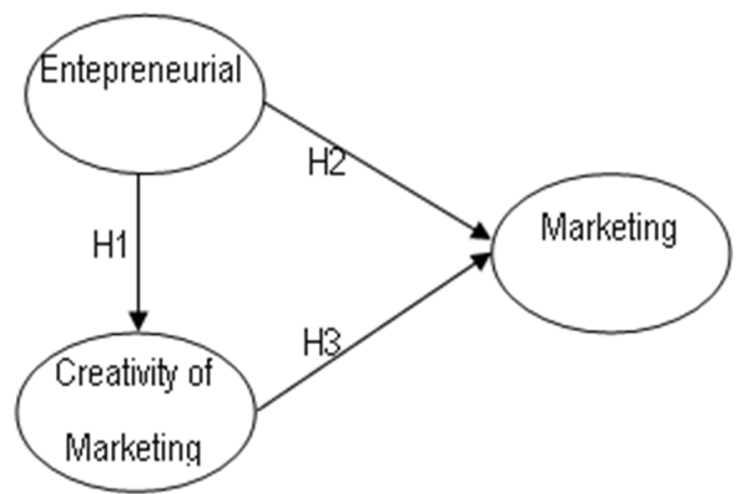

Fig 1. Mind Map Research Question

H1 Entrepreneurial orientation has a positive effect on the creativity of marketing programs;

H2 Entrepreneurial orientation has a positive effect on marketing performance;

H3 Marketing program creativity has a positive effect on marketing performance;

H4 Marketing program creativity mediates the effect of entrepreneurial orientation on marketing performance.

The population in this study were all Small and Medium Enterprises (UKM) in Kuningan Regency, West Java which were engaged in the processing industry with a minimum number 
of employees of 5 people, there were 21,334 companies. Because the population being the object of the study has non-homogeneous characteristics, the sampling technique used is the proportionate stratified random sampling method. The sample size was determined in accordance with the opinion of Hair et all. (1988) who stated that a representative sample size for analysis using the Structural Equation Model (SEM) ranged from 100 to 200 respondents. SEM (Structural Equation Modeling) analysis requires the use of a minimum of $5-10$ observations for each indicator so that if 14 indicators are determined, the total sample size is $10 \times 14=140$ respondents (Augusty, 2006).

To minimize the chance of generalization errors, it is strengthened by another method, namely the method developed by Slovin. From the calculation results of this study using the size of the observation so that the sample size is 187 respondents using the Maximum Likelihood Estimation technique. Methods of data collection using a survey method that uses a list of questions (questionnaire) to the respondent. Both in the form of closed questions and open questions. Meanwhile, to complement the research needs, direct interviews were also conducted to obtain additional required information that was not clearly explained in the questionnaire. For all the variables studied, the author provides a statement using a 7-point scale, namely for number 1 is a statement that strongly disagrees until number 7 for the value strongly agrees. To test the models and hypotheses in this study using the Structural Equation Model (SEM).

\section{Result and Discussion}

\subsection{Causality Testing of Structural Equation Modeling (SEM)}

After the model is analyzed through confirmatory factor analysis and it can be seen that each indicator can be defined as a latent construct, a full SEM model can be analyzed. The results of processing AMOS 16.00 are as follows:

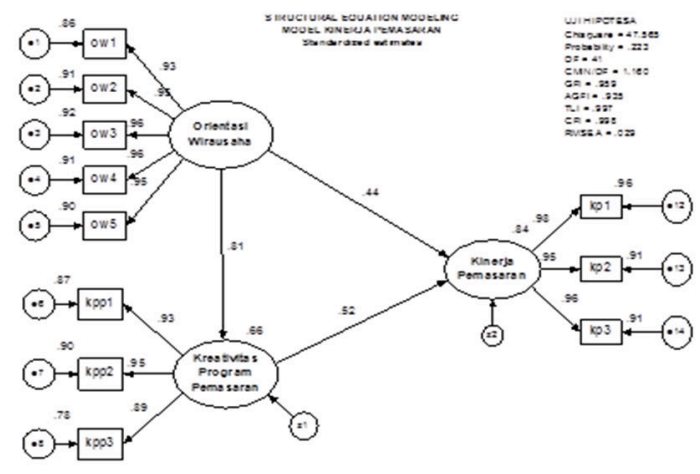

Fig 2. Structural Equation Modeling Factors Affecting Performance

Testing of the structural equation model is carried out by two types of testing, namely the suitability of the model and the test for the significance of causality through the regression coefficient test. The test of the suitability of the model shows that this model is suitable or fit for the data used in the study. This can be seen from the suitability index, namely: Chi-Square, Probability, CMIN / DF, GFI, AGFI, TLI, CFI and RMSEA all of which are well accepted. 
Table 1. Marketing Performance Model Feasibility Test

\begin{tabular}{lccc}
\hline $\begin{array}{c}\text { Goodness of fit } \\
\text { Index }\end{array}$ & $\begin{array}{c}\text { Cut-off } \\
\text { Value }\end{array}$ & $\begin{array}{l}\text { Result } \\
\text { Model }\end{array}$ & Information \\
\hline$\chi^{2}$ - Chi-Square & $\begin{array}{l}\text { Expected } \\
\text { small }\end{array}$ & 47,565 & $\begin{array}{l}\text { The value of } \chi^{2} \text { with DF 41 is } \\
56,942, \text { so that } \chi^{2} \text { count 47,565 } \\
\text { is less than 56.942 (Good } \\
\text { Category) }\end{array}$ \\
Probability & $\geq 0,05$ & 0,223 & Good \\
CMIN/DF & $\leq 2,00$ & 1,160 & Good \\
GFI & $\geq 0,90$ & 0,959 & Marginal \\
AGFI & $\geq 0,90$ & 0,935 & Marginal \\
TLI & $\geq 0,95$ & 0,997 & Good \\
CFI & $\geq 0,95$ & 0,998 & Good \\
RMSEA & $\leq 0,08$ & 0,029 & Good \\
\hline
\end{tabular}

The causality test developed in this model, it is necessary to test the hypothesis which states that the regression coefficient between the relationships is significant by looking at the C.R (Critical Ratio) value by looking at the $p$-value compared to $\alpha=0,05$.

Table 2. Standardized Regression Weight for Structural Equation Model Factors Affecting Marketing Performance

\begin{tabular}{|c|c|c|c|c|c|c|}
\hline & & & $\begin{array}{c}\text { Estimat } \\
\mathrm{e}\end{array}$ & $\begin{array}{l}\text { S.E } \\
.\end{array}$ & $\begin{array}{c}\text { C.R } \\
.\end{array}$ & $\mathrm{P}$ \\
\hline Creativity_Prog_Pms & $<---$ & $\begin{array}{l}\text { Entrepreneurial } \\
\text { Orientation }\end{array}$ & .804 & .055 & 14.500 & $* * *$ \\
\hline Marketing_performance & $<---$ & $\begin{array}{l}\text { Entrepreneurial_ } \\
\text { Orientation }\end{array}$ & .470 & .066 & 7.130 & $* * *$ \\
\hline Marketing_performance & $<---$ & Creativity_Prog_Pms & .561 & .068 & 8.299 & $* * *$ \\
\hline ow3 & $<---$ & $\begin{array}{l}\text { Entrepreneurial_ } \\
\text { Orientation }\end{array}$ & 1.042 & .039 & 26.706 & $* * *$ \\
\hline ow2 & $<---$ & $\begin{array}{l}\text { Entrepreneurial } \\
\text { Orientation }\end{array}$ & .992 & .038 & 26.434 & $* * *$ \\
\hline ow1 & $<---$ & $\begin{array}{l}\text { Entrepreneurial_ } \\
\text { Orientation }\end{array}$ & 1.000 & & & \\
\hline kpp3 & $<---$ & Creativity_Prog_Pms & .955 & .047 & 20.141 & $* * *$ \\
\hline kpp2 & $<---$ & Creativity_Prog_Pms & 1.043 & .042 & 25.013 & $* * *$ \\
\hline kpp1 & $<---$ & Creativity_Prog_Pms & 1.000 & & & \\
\hline kp1 & $<---$ & Marketing_performance & 1.000 & & & \\
\hline $\mathrm{kp} 2$ & $<---$ & Marketing_performance & 1.024 & .029 & 35.406 & $* * *$ \\
\hline kp3 & $<---$ & Marketing_performance & .969 & .027 & 36.435 & $* * *$ \\
\hline ow4 & $<---$ & $\begin{array}{l}\text { Entrepreneurial_ } \\
\text { Orientation }\end{array}$ & .998 & .037 & 26.630 & $* * *$ \\
\hline ow5 & $<---$ & $\begin{array}{l}\text { Entrepreneurial_ } \\
\text { Orientation }\end{array}$ & 1.062 & .041 & 25.795 & $* * *$ \\
\hline
\end{tabular}

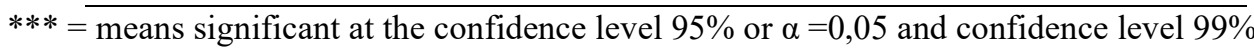
or $\alpha=0,001$ at two ends

Source: Primary data proceeded (2020)

In Table 2, it can be seen that the C.R. which is identical to the $t$ test in the regression, it can be seen that the $\mathrm{CR}$ value, all of the probability is $<0.05$, meaning that all exogenous variables have a significant effect on the endogenous variables. 


\subsection{Hypothesis test}

Hypothesis test conducted with level of significance $95 \%$ or $\square=0,05$.

Table 3. Values of C.R (Critical Ratio)

\begin{tabular}{llcc}
\hline & \multicolumn{1}{c}{ Variables } & CR & p \\
\hline 1 & Entrepreneurial Orientation $\rightarrow$ Marketing Program & 14,500 & 0,000 \\
& Creativity & & \\
2 & Entrepreneurial Orientation $\rightarrow$ Marketing Performance & 7,130 & 0,000 \\
3 & Marketing Program Creativity $\rightarrow$ Marketing Performance & 8,299 & 0,000 \\
\hline
\end{tabular}

Source: Primary data proceeded (2020)

The results of this study indicate that entrepreneurial orientation has a positive effect on the creativity of marketing programs. Entrepreneurial orientation to SMEs in Kuningan Regency, West Java has been able to increase the creativity of marketing programs. The entrepreneurial orientation in question is that UKM in Kuningan Regency has autonomy, meaning that it is not dependent on other people, namely in terms of capital, marketing production processes. SMEs innovate in their business in order to adapt to the needs and desires of consumers. Dare to take business risks, because the business that is carried out contains an element of risk, it is necessary to use technology that can provide business efficiency. Acting proactively looking for new business opportunities that can be a product of business diversification to cover the risks that may occur in old products and aggressively seeking profits by trying to find the cheapest raw materials and looking for new marketing so that the products are sold and the company gets a profit.

As obtained in the field, it is known that currently enthusiasts for superior products of SMEs in Kuningan Regency, West Java, continue to increase, both from local and outside consumers of Kuningan Regency. However, along with the increasing demand, the emergence of similar industries also increased. To anticipate this competition, many UKM players try to make innovations in product manufacture and packaging. It encourages new breakthroughs in creative ideas for new product creation and packaging. This cannot be separated from the use of better technology. They are also currently learning a lot and getting more information in making these new products. Not only obtaining information through newspapers, the ease of accessing television, telecommunication and internet media has had quite a good impact on them.

Based on the aforementioned conditions, it turns out that there is progress in increasing the entrepreneurial orientation of business people in Kuningan Regency, West Java, which in turn encourages the creativity of their marketing programs. The results of this study are in line with research which states a strong entrepreneurial orientation of entrepreneurs, it is very important because it has a good effect in encouraging one's marketing creativity (Amabile, 1996; Andrews, 1996; Sadi \& Al-dubaisi, 2007). Based on these findings, it means that if the entrepreneurial orientation of the UKM in Kuningan Regency, West Java increases, the creativity of the marketing program carried out by the UKM will increase.

The results of this study indicate that entrepreneurial orientation has a positive and significant effect on marketing performance. The implementation of the SME entrepreneurial orientation in Kuningan Regency, West Java, was able to improve the marketing performance of SMEs. The entrepreneurial orientation in question is that UKM in Kuningan Regency has autonomy, meaning that it does not depend on other people in terms of capital, marketing production processes. SMEs innovate in their business in order to adapt to the needs and desires of consumers. Dare to take business risks, because the business that is carried out contains an element of risk, it is necessary to use technology that can provide business efficiency. Acting proactively looking for new business opportunities that can be a product of 
business diversification to cover the risks that may occur in old products and aggressively seeking profits by trying to find the cheapest raw materials and looking for new marketing so that the products are sold and the company gets a profit.

Based on the results of the field evaluation, information was obtained that MSME actors in Kuningan Regency, West Java, currently in running their business are not too dependent on other pith. Especially with the government, banks, and other stakeholders. Because after all, because most of the businesses he is currently doing are hereditary, they are used to facing various complex problems in the field without the help of other parties. Some of them even stated that they did not want to receive revolving capital loan assistance from the government or financial institutions. They prefer to use the capital they currently have. In line with the increasing strong urge to always try and the continuous improvement of regional economic conditions, the growth of SMEs in Kuningan Regency, West Java continues to experience quite good growth.

The results of this study indicate that the creativity of marketing programs has a positive effect on marketing performance. The creativity of the marketing program for SMEs in Kuningan Regency, West Java has been able to improve their marketing performance. The intended creativity of the marketing program is the search for good information about the production process, raw materials and markets that require products from SMEs. The products of UKM in Kuningan Regency in agribusiness such as tofu products, jeuk lime syrup which are the superior products of Kuningan Regency and snacks because Kuningan Regency for tourism is also developed, so this is a market for UKM. To spur the creativity of the marketing program, there were many discussions on marketing programs with related agencies, namely the Kuningan Office of Cooperatives and SMEs, which had been done a lot to encourage SMEs to innovate in their marketing programs.

The compatibility of the marketing program with the ability of SMEs in producing their merchandise has been done a lot, such as making production for specific lime syrup packaging for Kuningan Regency, special tofu packaging for Kuningan regency, specific tape packaging and others. UKM is also active in surveying customers to find out market tastes both in the city and outside the city so that the products of UKM in Kuningan Regency can be seen in various cities such as Bandung, Cirebon and even to Purweokerto and Jogyakarta, especially its lime syrup. Kuningan District UKM often holds meetings with the Regency Government through the Cooperative and UKM Service in the development of UKM Kabupaten Kuningan which is based on local wisdom by using local raw materials so that the dependence of raw materials on suppliers is expected to be small and will give SMEs a competitive advantage in Kuningan Regency, West Java. And this event is used by SMEs to share experiences with fellow entrepreneurs and create products according to customer desires. Based on these findings, it means that if the creativity of the marketing program of UKM in Kuningan Regency, West Java increases, the marketing performance of SMEs will increase.

The results of the study based on standardized regression weight show that the indirect effect of entrepreneurial orientation on marketing performance through marketing program creativity is 0.424 with a total effect of 0.865 . As it is known that all the variables studied were significant at the $5 \%$ and $1 \%$ significance levels. So it can be said that the creativity of the marketing program is indeed an intervening variable. This is even more convincing that if the entrepreneurial orientation of a businessman increases, then supported by the creativity of a good marketing program, it will be able to improve marketing performance. 


\section{Conclusion}

The conclusion of this research on SMEs in Kuningan Regency, West Java, there are four important points of concern. It is known that entrepreneurial orientation has a positive effect on the creativity of marketing programs, meaning that the increasing the entrepreneurial orientation of SMEs the more creative the marketing programs are. Increasing entrepreneurial orientation can also improve the marketing performance of SMEs. Likewise, the creativity of marketing programs has a positive impact in improving marketing performance. Finally, it is known that the creativity of marketing programs is able to mediate the effect of entrepreneurial orientation on marketing performance. This means that differences in opinion between previous researchers can be explained by adding to the mediating variable.

Based on the above conclusions, to improve marketing performance, SMEs in Kuningan Regency, West Java must be more entrepreneurial-oriented and better by reducing dependence on other people regarding capital, raw materials and others. In addition, to improve the marketing performance of SMEs, it is necessary to increase the creativity of their marketing programs by actively conducting customer surveys to determine customer wants and needs, conducting comparative studies with fellow entrepreneurs in creating products according to customer desires. The serious support from the Kuningan Regency Government is very important, especially in mentoring, training, marketing assistance, and helping find solutions to capital problems for SMEs.

Future research can be carried out by adding a moderating variable, namely environmental factors (Gómez-Haro et.al., 2011). Okhomina (2010) states that psychologically, environmental factors can moderate the relationship between entrepreneurial orientation in improving marketing performance. This research is also supported by the results of research by Crvelin (2006) dan Acs and Amorós (2008).

\section{References}

[1] Acs, Z. J., \& Amorós, J. E. (2008). Entrepreneurship and competitiveness dynamics in Latin America. Small Business Economics, 31(3), 305-322. https://doi.org/10.1007/s11187-008-9133-y

[2] Amabile, T. M. (1996). Creativity and Innovation in Organizations. Harvard Business School.

[3] Andrews, J. (1996). Creative ideas take time: business practices that help product managers cope with time pressure. Journal of Product \& Brand Management, 5(1), 6-18.

[4] Augusty, F. (2000). Manajemen Pemasaran: Sebuah Pendekatan Strategik. Program Magister Manajemen Universitas Diponegoro.

[5] Augusty, F. (2006). Metode Penelitian Manajemen. Semarang: Badan Penerbit Universitas Diponegoro.

[6] Awang, A. B., Said Asghar, A. R. B., \& Subari, K. A. B. (2010). Study of Distinctive Capabilities and Entrepreneurial Orientation on Return on Sales among Small and Medium Agro-Based Enterprises (SMAEs) in Malaysia. International Business Research, 3(2), 34-48. https://doi.org/10.5539/ibr.v3n2p34

[7] Baker, W. E., \& Sinkula, J. M. (2009). The complementary effects of market orientation and entrepreneurial orientation on profitability in small businesses. Journal of Small Business Management 47(4): 443-464.

[8] Crvelin, A. K. (2006). MARKET ORIENTATION AND COMPETITIVENESS OF CROATIAN SMEs. In In An Enterprise Odyssey. International Conference Proceedings (pp. 1575-1585). niversity of Zagreb, Faculty of Economics and Business. 
[9] Dzogbenuku, R. K., \& Keelson, S. A. (2019). Marketing and entrepreneurial success in emerging markets: the nexus. Asia Pacific Journal of Innovation and Entrepreneurship, 13(2), 168-187. https://doi.org/10.1108/apjie-12-2018-0072

[10] Ferreira, J., \& Coelho, A. (2020). Dynamic capabilities, innovation and branding capabilities and their impact on competitive advantage and SME's performance in Portugal: the moderating effects of entrepreneurial orientation. International Journal of Innovation Science, 12(3), 255-286. https://doi.org/10.1108/IJIS-10-2018-0108

[11] Frank, H., Kessler, A., \& Fink., M. (2010). Entrepreneurial O rientation and B usiness P erformance - A R eplication S tudy **. Schmalenbach Business Review, (April), 175-198.

[12] Gómez-Haro, S., Aragón-Correa, J. A., \& Cordón-Pozo, E. (2011). Differentiating the effects of the institutional environment on corporate entrepreneurship. Management Decision, 49(10), 16771693. https://doi.org/10.1108/00251741111183825

[13] Gunawan, W. H. (2018). Faktor-Faktor Keunggulan Bersaing Dan Implikasi Terhadap Kinerja Perusahaan. Indonesian Journal Of Strategic Management, 1(2), 1-9.

[14] Hair, J. F., Black, W. C., Babin, B. J., Anderson, R. E., \& Tatham, R. L. (1988). Multivariate data analysis ((Vol. 5, N). Upper Saddle River, NJ: Prentice hall.

[15] Jin, B., \& Cho, H. J. (2018). Examining the role of international entrepreneurial orientation, domestic market competition, and technological and marketing capabilities on SME's export performance. Journal of Business and Industrial Marketing, 33(5), 585-598. https://doi.org/10.1108/JBIM-02-2017-0043

[16] Kang, S., Hur, W. M., \& Kim, M. (2014). The mediating role of alliance marketing program creativity on the relationship between alliance orientation and market performance in the services industry. Managing Service Quality, 24(5), 522-540. https://doi.org/10.1108/MSQ-10-2013-0233

[17] Lindsay, N. J. (2005). Toward A Cultural Model of Indigenous Entrepreneurial Attitude. Academy OfMarketing Science Review, 2005(05).

[18] Mamun, A. Al, Mohiuddin, M., Fazal, S. A., \& Ahmad, G. Bin. (2018). Effect of entrepreneurial and market orientation on consumer engagement and performance of manufacturing SMEs. Management Research Review, 41(1), 133-147. https://doi.org/10.1108/MRR-04-2017-0102

[19] Masa'deh, R., Al-Henzab, J., Tarhini, A., \& Obeidat, B. Y. (2018). The associations among market orientation, technology orientation, entrepreneurial orientation and organizational performance. Benchmarking, 25(8), 3117-3142. https://doi.org/10.1108/BIJ-02-2017-0024

[20] Okhomina, D. (2010). Entrepreneurial orientation and psychological traits: the moderating influence of supportive environment. Journal of Behavioral Studies in Business, 3, 1-16. Retrieved from http://gdex.dk/ofdi/14 Kaya Harun.pdf\%0Ahttp://www.aabri.com/manuscripts/10450.pdf

[21] Sadi, M. A., \& Al-dubaisi, A. H. (2007). Barriers to organizational creativity The marketing executives ' perspective in Saudi Arabia. Journal of Management Development, 574-599. https://doi.org/10.1108/02621710810877839

[22] Santos, I. L. dos, \& Marinho, S. V. (2018). Relationship between entrepreneurial orientation, marketing capability and business performance in retail supermarkets in Santa Catarina (Brazil). Innovation \& Management Review, 15(2), 118-136. https://doi.org/10.1108/inmr-04-2018-008

[23] Slater, S. F., Hult, G. T. M., \& Olson, E. M. (2010). Factors influencing the relative importance of marketing strategy creativity and marketing strategy implementation effectiveness. Industrial Marketing Management, 39(4), 551-559. https://doi.org/10.1016/j.indmarman.2008.03.007

[24] Smith, B., \& Jambulingam, T. (2018). Entrepreneurial orientation: Its importance and performance as a driver of customer orientation and company effectiveness among retail pharmacies. International Journal of Pharmaceutical and Healthcare Marketing, 12(2), 158-180. https://doi.org/10.1108/IJPHM-07-2017-0038

[25] Wahyuni, N. M., \& Sara, I. M. (2020). The effect of entrepreneurial orientation variables on business performance in the SME industry context. Journal of Workplace Learning, 32(1), 35-62. https://doi.org/10.1108/JWL-03-2019-0033 